\title{
Legislative Cross-carpeting, Multiparty System and the Challenges of Democratic Good Governance in Nigeria
}

\author{
Mayowa Joseph OLURO \\ Political Science and Public Administration Department \\ Adekunle Ajasin University, Akungba-Akoko, Ondo State, Nigeria \\ E-mail: mayowa.oluro@aaua.edu.ng \\ $\&$ \\ Johnson Olawale BAMIGBOSE (Corresponding Author) \\ Political Science and Public Administration Department \\ Adekunle Ajasin University, Akungba-Akoko, Ondo State, Nigeria \\ E-mail: johnson.bamigbose@aaua.edu.ng
}

Received: Sep. 8, 2020 Accepted: Dec. 31, 2020 Online published: Jan. 3, 2021

doi:10.5296/jpag.v11i1.18151ＵRL: https://doi.org/10.5296/jpag.v11i1.18151

\begin{abstract}
The legislature is unarguably the fulcrum upon which democracy rests. Democracy, in this context, is representative government. Thus, the institution of the legislature as an assembly of elected representatives becomes the engine room of the structural framework upon which democratic governance is built. As history has shown, the beauty of legislature is greatly enhanced by a healthy multi-party system wherein elected representatives from different party backgrounds engage one another alongside party ideological positions with a view to deliberating on issue of governance and socio-economic well-being of the people. Legislative cross-carpeting in Nigeria is becoming a norm rather than exigency, and is taking a negative toll on the capacity of legislatures to fulfill their mandates as against functioning as merely rubber-stamp annexes of the executive/ruling party. This study examines the impacts of the wanton cross-carpeting, often times bereft of any ideological underpinning, that have characterized legislative assemblies in Nigeria and its implications on good governance. Among others, it concludes that concrete legal and political frameworks must be developed to check the direction of cross-carpeting in Nigeria's legislative houses if good governance is to be entrenched.
\end{abstract}

Keywords: legislature, cross-carpeting, multi-party system, good governance and democracy 


\section{Introduction}

The persistence of cross-carpeting has greatly influenced Nigerian politics in a number of ways but its ugly head is more felt in the bad governance characterized with Nigeria. Indeed, the pattern and productivity of legislative business in Nigeria suggests an underutilization of a critical democratic institution germane not only to the proper functioning of democracy but to its very survival. It would seem, as current observations have proven, that most legislative houses in Nigeria are mere rubber stamp annexes of their respective executive arms of government, thereby weakening significantly their capacity to provide quality representation for the people, as well as serve as a veritable avenue for social engineering to promote good governance and positive democratic dividends.

Legislative assemblies are by default composed of elected representatives of the people. They indeed come from delineated constituencies recognized by law and are expected to project the interests of these constituencies, aggregating them into concrete decisions and legal instruments to better achieve good-governance. In a typical democracy, and especially one characterized by multi-party systems as in Nigeria, it is common to have members elected on the platforms of different political parties in state legislatures.

It is assumed that individuals are elected based on the preference for the programmes and manifestoes of their political parties in the respective constituencies, which in turn guides their posture, stance and general reaction to governance issues and the business of legislation. Implicit in this assumption is the role of the opposition in keeping the political party in general control of executive power in check and ensuring that the preferences and interests of their constituencies are recognized, reflected and effectively addressed in governance.

Awofeso and Irabor (2016) declared that multi-party democracies need multiple political parties, where one serves as the ruling party and others as oppositions and alternatives. The point here is that in a democratic setting, ruling party and opposition party/parties stand side by side as the opposition parties serve as the watchdogs to checkmate and put the ruling party on toe as this promotes democratization. However, the wantonness and lack of restraint lawmakers often exhibit in the issue of switching party allegiance remains a formidable threat against the consolidation of multi-party democracy and entrenchment of democratic good governance in the country. Based on available evidence, cross-carpeting or party switching has become the order of the day among lawmakers and politicians alike, at the slightest threat to their interest in Nigeria. Though, it started prior independence but its ugly head becomes evident and widespread in the current republic. It has been a very serious task to retain party members alongside ideological inclination that is tailored towards nation building and overall interest on the nation. Cross-carpeting which is also known as party defection is the 'movement or crossing' of political players (elected public officials, party chieftains and supporters) from one political party to the other, especially from the opposition parties to the ruling party either at the national or state levels as evident in Nigeria. It is more or less the shifting or switching of allegiance from one political party to the other. This became very prominent in the eve of 2015 Nigeria General Elections where legislative members and state governors cum supporters defected from Peoples Democratic Party (PDP) to All Progressives 
Congress (APC). Eme and Ogbochie (2014) opinionated that the wave of defection from one party to another in the National Assembly has been the case of different strokes for different folks. In the House of Representatives, elected members defect from one party to another unhindered by the leadership of the House and Senate. Similar occurrence also persists in the states House of Assembly where members defect or cross-carpet at will not minding their political party affiliation which can disrupt the organization of such party in that level.

In lieu of this discussion, this paper sets out to unravel the rationale behind legislative cross-carpeting in Nigeria's multiparty democracy and its adverse implications on the country's democratic good governance using the present fourth republic as the template.

\section{Statement of Problem}

Political party cross-carpeting among politicians has taking a centre page in Nigeria's political space. Quite a number of politicians have "exchanged" political parties in a number of times in Nigeria. It has also become commonplace for members to cross from the political party on whose platforms they were elected into the house to another one, usually the ruling party (Yakubu and Bamalli, 2019; Awofeso and Irabor, 2016; Opadere and Alana, 2015). This is in fact almost always the case when a party other than their own captures executive power. This phenomenon has been witnessed in Ekiti, Imo, Ondo, Edo, Rivers, Bayelsa, Bauchi etc. in recent years (Nwokeoma, 2020). In Imo state for instance, the House of Assembly was dominated by members elected under canopy of the People's Democratic Party (PDP) which also controlled executive arm, before the Supreme Court's final judgment that declared the All Progressive Congress' (APC) candidate (Hope Uzodinma as the winner ) in the last gubernatorial elections. As soon the tide turned, the PDP lost its overwhelming majority overnight with many of its members, including the speaker, jumping ship to the APC. Similarly, Edo state of Nigeria witnessed another political atmosphere bedevilled by unprecedented party defection. The state governor in person of Godwin Obaseki parted way with All Progressives Congress (APC) and pitched his tent with PDP as a result of irreconcilable differences with his political godfather (Adams Oshiomole) which also necessitated the removal of Adams Oshiomole as APC national chairman. The case necessitated various defections from both parties. Forty-two cabinet members of Godwin Obaseki defected to the APC in the struggle but the governor was re-elected in an election adjourned to be free, fair and credible.

In spite of the available works on party defection in Nigeria political system, there is dearth of studies specifically addressing the particular impacts of cross-carpeting on democratic good governance in Nigeria. In filling this gap, this paper argues that the phenomenon of party cross-carpeting in legislative houses across the country is not only hurting the institution itself in terms of perceptions about its capacity and relevance among citizens but indeed seems to be making a mockery of the whole idea of democratic good governance. This position rests on a number of empirical evidences characterizing the Nigerian political clime in recent times. Some of these includes diminished representation, implied voters' disenfranchisement, diminished quality of legislative debates, diminished relevance of the legislature in real democratic terms, state capture, stunted democratic growth. These 
variables are of course not mutually exclusive, they reinforce one another and indeed some of them serve to perpetuate others. We will treat each of them in the coming sections but our attention will be focused first on conceptual clarifications and review of related literatures.

\section{Methodology}

This paper adopted analytical and descriptive methods of social inquiry. It as well adopted secondary source of data collection with the utilization of relevant textbooks, journals, newspapers and articles. This is considered apt as it helped to unpack the trends of cross carpeting in Nigeria legislative political history with its attendant ideological bareness visible with Nigerian political parties.

\section{Conceptual Clarifications and Review of Related Literatures}

\section{Legislature and Cross-Carpeting}

Legislature is the beginning and the end of democracy. The origin of legislative body could be traced to classical Athens and it was known as Ekklas LAldu Dhimou meaning the assembly of polis. The polis means city at that time. Also, in Rome it was called Roman Comilia Canata (Busari, 2005). Legislatures are elected body with the primary responsibility of making laws for the country. However, in the real sense of it, legislatures do more than law-making. To have a deeper understanding of legislature is to delve into its democratic roles. Nwaubani (2004) cited in Yakubu and Bamalli (2019) claims the centrality of legislative functions as embedded in democratic values are to amongst other ensure effective policy making, ensure good governance as well as the hindrance of executive absolutism in the business of governance. Similarly, legislature refers to a formal body, usually chosen by election and empowered by constitutional provisions to legislate on public/private bills with a view to making, changing and repealing of laws; as well as powers to represent the constituent units and control government (Lafenwa, 2002). Furthermore, Loewenberg (1995) cited in Yakubu and Bamalli (2019) averred that legislatures refer to assemblies of elected representatives from geographically defined constituencies, harnessed with the responsibility of law-making apparatus in the business of governance. It is within this premise that legislatures connote the assemblies of elected public officials to make law, represent their people and also contribute to policy making act of government towards ensuring and assuring democratic good governance.

Cross-carpeting is not a new thing in democratic systems. In fact, as some scholars have pointed out, it is one of the necessary implications of the principles guiding democratic practice, which in some countries is in fact constitutionally recognized. The Nigerian Constitution for instance, permits serving members of the legislature to change political parties if there is a crisis that have led to the factionalization of the party on which they were elected into the house (Sections 68 subsection 1(g) and 109 subsection 1(g) of the 1999 Constitution of the Federal Republic of Nigeria (CFRN) as amended in 2011). It is valid to state that party switching, defection or to use the language of this paper legislative cross-carpeting is not peculiar to Nigeria alone (developing democracy) rather it is a global phenomenon though with more occurrences in developing democracies. 
Instructively, the term 'cross-carpeting' has been used interchangeably with concepts like party defection, party switching, floor-crossing, party-hopping, canoe-jumping, decamping, party-jumping (Blunt, 1964; Chang, 2009; Fashagba, 2014; Awofeso and Irabor, 2016). As a conceptual and analytical category however, legislative cross-carpeting essentially entails a situation whereby a serving member of a legislative house switches allegiance from the political party on whose platform he/she was elected into the house, to another party irrespective of constitutional provision. Originating in the British Parliament, in which members from the party in government and those from the party(ies) in opposition sit facing each other on rows of benches, the term meant that a member switches parties would literally also have to choose which side of the chamber they sit on.

Originally and indeed in established democracies, cross-carpeting almost always symptomizes irreconcilable ideological differences, political persecution based on divergent interests or both. Historically, it has hardly ever been the case in Nigeria. Indeed, the first incidence of cross-carpeting in Nigeria was predicated more on political calculations based on ethnic sentiments rather than any ideological persuasion (Okpu, 1985; Osaghae, 2000).

Since 1999 till date, there are several cases of cross-carpeting especially during the electoral cycle and various factors are responsible for these unprecedented defections in African democratic experience. In explaining this growing phenomenon, Olu and Irabor (2016) noted that party formation is often driven by political careerism rather than ideology. This explains why politicians rarely feel any sense of ideological attachment at any sign of danger to their individual political interests. For Yakubu and Bamalli (2019), the phenomenon could be attributed to both individual and institutional factors. According to them, the individual is motivated by self-interest and selfish calculations which must be actualized by every means possible, thus making the individual politician what they call a "political entrepreneur". Conversely, institutional factors range from "centralized and personalistic nature" of the polity to institutional sabotage (Yakubu and Bamalli, 2019).

This paper also argues that an important factor contributing to party-cross carpeting is the weak or even non-existent connection between legislators and their constituencies (who are supposed to have elected them based on individual/party popularity), which is attributable to the parochial political culture that pervades the Nigerian polity. In real terms, there exists low capacities for making representatives accountable to their constituencies thereby making it very easy for these representatives to pursue self-interested agendas.

\section{Political Parties}

Every society selects or elects their leaders via different methods and these have consequential effects on the kind of leaders such society will provide which in turn determines the extent of good governance and overall structural transformation of such society. A democratic society offers regular opportunities to vote new individuals to ruling positions, this can be done through formation of political parties, political parties are therefore undoubtedly fundamental institutions of the democratic process (Omotoso, 1997). However, democracy thrives more efficiently on competitive political parties that are built on ideological inclinations rather than ethnic bigotry with the sole objective of controlling public 
offices, and by extension are also willing to serve the purpose of effective watchdog to the party in power, especially with regard to protecting the interests of the polity at large.

Etymologically, Lapalombara and Weiner (1966) noted that political parties are primarily a phenomenon of the 18th century. In England, the modern party really got under way with the organization of the local societies favoured by the liberals after the reform of 1832. In France and other European countries, the transformation of legislative cliques or political clubs into mass-oriented organizations is associated with the revolutionary year of 1848. In the United States, which is generally regarded as the model of modern democracy, parties with substantial following stable structures appeared in the 1790s with the federalists of Hamilton and Adams and the Republicans of Jefferson and Madison (Janda, Berry and Goldman, 1992).

It is apposite to state that political parties play critical roles in democratizing. Political parties serve as the foundation upon which democracy is built. IDEA (2000) noted that political parties produce the candidates, set the parameters of issues and agenda within which elections are to be held and they are expected to perform these duties periodically. Political parties perform quite a number of functions. Carr in Egbewole and Muhtar (2010) and Lamidi and Bello (n.d) concisely summarized the functions of political parties as follows:

1. Stimulating the citizenry to take a greater interest in election and activities of government.

2. Defining political issues of the day and sharpen the choice between alternative paths.

3. Presenting candidates who are committed to announce position with respect to issues.

4. Majority party provides basis upon which government can be operated.

5. Accepting responsibility to govern upon winning election.

\section{Party Ideology}

The term ideology is from the French word 'ideologie' meaning the science of ideas. It was coined by a French philosopher, Antonio Destutt de Tracy during the French Revolution (Heater, 1964). Rodee, Anderson, Christol and Green (1976) defined political ideology as the values or principles that those who exercise or seek political power refer to in order to lend legitimacy to their acts. In a more comprehensive manner, Christenson, Engel, Jacobs, Rejai and Watzer (1972) viewed ideology as the belief system that explains and justifies a preferred political order for society, either existing or proposed, and offers a strategy for its attainment. Christenson et al (ibid) further averred that ideology includes a set of basic assumptions, both normative and empirical, about the nature and purpose of man and society.

Party ideology is the political principle, doctrine or philosophy that guides the operation of the political party. It is the party identification label that helps to know and understand what a political party stands for. Apparently, party ideology is generated from close observation of the nation's socio-economic and political issues of the state, then, political parties faction out ideological inclinations to solve such problems. Party ideology serves as the bait to attract 
members and electorates into such political party. It is the blueprint plan through which party manifesto and even the policies of government are generated.

As enunciated earlier, it is apposite to declare that democratic process is a function of very virile ideological and strong political parties and that without the prospective of political parties, there is likely going to be contradictions, instability and incoherence in a nation's democratic enterprise. It should be noted that the constitution of any nation determines the number of parties that is legally allowed. In the case of Nigeria constitution, multiparty system is legally allowed.

\section{Party System}

Party system is the network and typical structure of political parties in a political system. Party system has been categorized according to numerical divisions. Party systems can be identified as patterns of interaction among political parties in electoral, parliamentary and governmental arenas of a given political context (Adeniran, 2015). However, three systems are usually identified namely, one party system, two party system and multiparty system. One party system refers to a situation in which only one party is constitutionally allowed to exist and then control the government of the state. Any minor party that struggle to exist are categorized as treason. It started as an idea in the defunct Soviet Union with the introduction of communism as a state ideology. The introduction of the one party system into Africa was mainly instigated by the desire to quicken the pace of social and economic development. Though, this system has no element of democracy and thus has been described as 'representative dictatorship' (Adetola, 1992).

According to La Palombara and Weiner (1966), "In a two-party system, control of government power shifts between two dominant parties. Two-party systems most frequently develop when electoral victory requires only a simple plurality vote, that is, the winner gets the most votes, but not necessarily a majority of votes. In such a system, it makes sense for smaller parties to combine into larger ones or to drop out altogether. Advocates of two-party systems believe they limit the dangers of excessive fragmentation and government stalemate".

Multiparty system normally arises when there are more than two political parties existing in a particular society and in some instances without any of the parties being able to win the majority. It is therefore characterized with coalition or alliances in order to form the government and very common in multi-ethnic society like Nigeria. Adeniran (2015) added that parliamentary governments based on proportional representation often develop multiparty systems. In this type of electoral arrangement, the number of legislative seats held by any party depends on the proportion of votes they received in the most recent election.

Multi-party system has always been a part of the political system in Nigeria. Indeed, during both the first republic and second republic, there was a proliferation of political parties in the nation's democratic space. However, during short-lived the third republic, the country adopted a two party system, by allowing the registration and operation of only two political parties - (Social Democratic Party (SDP) and the National Republican Convention (NRC) - 
under the leadership of the then military head of state, General Ibrahim Babangida. The current fourth republic which began on May 29th 1999 has witnessed the return of multiparty democracy in the Nigerian political terrain.

\section{Democracy}

The word democracy has been described as the transliteration of the Greek word Demokradia which means government by the people, the right of all to decide what are matters of general concern and what shall be done about them. Though, direct representation was only applicable in a small Greek city-state. Overtime, democracy as a concept suffers definitional plurality as different scholars have defined based on their views. Almond, Powell, Strom and Dalton (2004) defined democracy as a political system in which citizens enjoy a number of basic civil and political rights and in which their most important political leaders are elected in free and fair elections and accountable under the rule of law.

Robert Dahl (1982) averred that "democracy is a system of elected representative government operated under the rule of law, where the most significant groups in the population participate in the political process and have access to effective representation in the practice of making governmental decisions, that is, of allocation of scarce resources". Democracy is also a process of democratization in any democratic society. Heater (1964) views democracy as a form of government, a way of life, or an attitude of the mind. Heater (ibid) furthers stated that democracy is essentially a method of organizing society politically and argued that the following elements equality, sovereignty of the people, respect for human life, the rule of law and liberty of the individual makes a country democratic.

Claphan (1994), Ghali (1995) and Held (1993) cited in Oke (2010) declares that democracy provides a veritable platform for the entrenchment and consolidation of good governance through institutional arrangements of citizens' participation. However, the evidence shows that the ongoing democratic experimentation in Nigeria since 1999 is yet to engender good governance with the recent description of Nigeria as a worst zone of poverty.

\section{Good Governance}

Governance simply means the act or manner of governing or the way of control. It is the process by which decisions are made and implemented. Various contexts in which governance can be used are corporate governance, international governance, national governance and local governance (Sharma, Sadana and Kaur, 2012). Sharma e tal. (2012) defined governance as the manner in which authority, control or power of government is exercised in mobilizing a society's social and economic resources, to add the issues of public interests. In a true sense of it, governance transcends beyond the state to incorporate within itself, the civil society organizations and political parties.

Good governance is a phenomenon that depends on the efficient functioning of the three arms of government and its branches. The World Bank in one of its documents in 1982 highlighted four dimensions of good governance to include public sector management, accountability, legal framework for development and information and transparency. Later in 1992, World Bank's document entitled Governance and Development said, good governance is central to 
creating and sustaining an environment, which fosters strong and equitable development and it is an essential complement to sound economic policies. Good governance includes both a broad reform strategy and a particular set of initiatives to strengthen the institutions of civil society with the objective of making government more accountable, more open and transparent and more democratic (Minogue, 1997).

We can therefore infer that good governance is a tradition which ensures that the institutions of government are responsible to the electorates in terms of delivery. The elements of good governance include accountability, participation, transparency, rule of law, consensus oriented, effectiveness and efficiency, responsiveness and inclusiveness and equity.

\section{Theoretical Framework}

Structural functionalism has been found useful and apt in the examination and comparison of political systems. This is because the approach sees every sector of the society as functional. In a representative democracy however, the three arms of government namely legislature, executive and judiciary have different functions to perform. All these functions are to ensure and assure democratic good governance.

The proponents of this theory include Emile Durkheim, Talcott Parsons, Gabriel Almond among others but the latter brought the theory to the centre-piece of political discuss. Gabriel Almond (1966) declares that every political system performs certain functions. Taking Easton's systems analysis as a starting point, Almond looks for the functions which could be included among the input and output functions of all political systems. Almond (ibid) further reiterated that the functioning of any political system may be viewed in terms of its capabilities defined as the way it performs as a unit in its environment. The concepts of regulative, extractive, distributive and responsive capability are employed as criteria to assess how a system is performing within its environment, how it is shaping its environment and how it is being shaped by it.

The central theme of this theory is that each unit of the political system has certain responsibility to carry out and that any attempt at shifting this responsibility will amount to failure and total decline in the realization of any objective set within the political milieu.

Consequently, from a structural-functionalist perspective, the legislature plays both vital and vibrant roles to ensure the survival and sustainability of democracy in the area of law making and representation. This is because the legislature is very important in debating issues, scrutiny of bills and budget which forms the basis upon which good governance is premised. It also ensures the expected transparency in government through its watchdog attribute and oversight functions.

\section{Implications of Legislative Cross-Carpeting on Democratic Good Governance in Nigeria}

The current trend of Legislative cross-carpeting has a number of grave implications for good governance in Nigeria. They include:

\section{i. Diminished Representation}


In Nigeria, it is assumed elections are won through popular vote by individuals sponsored by a political party. Based on this logic, legislators representing particular constituencies should do so due to the mandate they have received from such constituencies through the popularity of their political platform. The increased, indiscriminate and wanton frequency of cross-carpeting is making a mockery of this ideal, and by implication reduces the chances of quality representation. Indeed, legislators appear nowadays to be more concerned about their own political future than sponsoring bills and engaging in legislative enterprises that serves the interests of those who elected them. A case in point is the recent drama that ensued in the Imo State House of Assembly earlier referenced in the opening section. As noted by Nwokeoma (2020), the charade in Imo state only serves to reveal the damning reality of dispensability of the electorates, especially after elections.

\section{ii. Diminished quality of legislative enterprise}

Opposition politics is not an attractive venture in Nigeria. As Yakubu and Bamalli (2019) argue, "more than often we hear of instances where oppositions are marginalized and reduced to mere onlookers by ruling parties in Nigeria". This winner-takes-us-all mentality that characterizes the political space ultimately serves to disincentivize any pretension to belonging to the opposition because it would mean having to give up the perceived largesse (patronages, benefits and security) that joining the ruling party may offer. It follows therefore that legislators who jump ship for the overriding purpose of preserving their own self-interest may have little or nothing to offer when it comes engaging in quality legislative enterprises that serve to actualize the aspirations, sensibilities, values and interests of their constituents, and as such undermine good governance.

\section{iii. Diminished relevance of the legislature in real democratic terms}

This perhaps is greatest danger that unchecked and wanton cross-carpeting devoid of ideological underpinning portends. If democracy is representative government with representation being most actualized through legislative assemblies, it follows that any disinterest or lack of confidence the citizens may harbor about such an institution serves not only to minimize its importance but indeed undermine the very essence of democracy, good governance. Unfortunately, it would seem legislators are unaware of the strategic importance of hallowed chambers in the democratic governmental process, which explains why they continue to ridicule it through incessant cross-carpeting.

\section{iv. Stunted democratic growth}

On a final note, indiscriminate cross-carpeting by legislators is antithetical to democratic growth and stability, which are necessary preconditions for good governance. In the first instance, it gives the ruling party opportunities to operate without constructive criticism. Secondly, in extreme cases of cross-carpeting where number of public representatives who defected are significantly high, such shifts of allegiance have led to the collapse of democratically elected governments, such as in Lesotho in 1997 (Hoeane, 2008). As such, cross-carpeting of elected office holders who do not resign the first platform for coming to political position do not add value to the process of democratic consolidation. 


\section{Conclusion and Recommendation}

The work examined the undue political prostitution among legislative members as well as public officials which has been the defining feature of the Fourth Republic in Nigeria and its bad influence on democratic good governance in the country. This has in numerous ways erodes the competitive and rigour associated with debates over policies in the floor of the legislative assembly in the country. It is believed that the proper scrutiny of issues based on different ideologies of legislative members coming from divergent political parties makes policies pragmatic and visible in an attempt to promote democratic good governance in any democracy. Therefore, the recent incidences of cross-carpeting in legislative houses especially in the last six years suggests that urgent and drastic measures need to be taken to forestall and prevent a total disintegration of the democratic structures of the Nigerian government and promote good governance. Among other things, there is need for systematic citizen mobilization and engagement by civil society and vigorous enlightenment by the media to bring an end to this reign of transactional politics and political entrepreneurization that favours only the politicians in order to unleash the potent force of democracy in Nigeria. The need for concrete legal and political frameworks must be developed to check the direction of cross-carpeting in Nigeria's legislative houses if good governance is to be entrenched. On a final note, there is the need to emphasis more on party ideology among political parties and strict adherence to such doctrine by politicians as this will reduce the incidence of cross-carpeting in Nigeria democracy.

\section{References}

Adeniran, A. (2015). Analytical Study of Political Party system in Nigeria. Public Policy and Administration Research, 5(12).

Adetola, I. O. (1992). Government for GCE: A Modern Approach, Ibadan: Evans Brothers Nig. Ltd.

Agbaje, A. (1999). In Anifowose, R. and Enemuo, F. (eds) (1999). Elements of Politics, Lagos, Nigeria: Malthouse Press Limited.

Aleyomi, M. (2013). Election and Politics of Party Defection in Nigeria: A Clue from Kogi State. Covenant University Journal of Politics and International Affairs (CUJPIA), 1(1), 72-84.

Aleyomi, M. B. (2014). Renewing Nigeria's Democracy: The Role of Political Party System Viability. The Journal of Pan African Studies, 6(10).

Almond, G. A. (1966). Introduction: A Functional Approach to Comparative Politics in Gabriel A. Almond and James S. Coleman (eds.), The Politics of Developing Areas, Princeton: Princeton University Press.

Almond, G. A., Powell, G. B., Strom, K., \& Dalton, R. J. (eds.) (2000). Comparative Politics Today: A World View. Singapore: Pearson Education, Inc.

Awofeso, O., \& Irabor, P. A. (2017). The Game Theory and the Politics of Cross-carpeting in 
Nigeria's Fourth Republic. Journal of Public Administration and Governance, 7(7).

Awofeso, O., \& Irabor, P. A. (2016). Party Cross-carpeting in Nigeria's Fourth Republic: Cases and Causes. Journal of Public Administration and Governance, 6(3), 31-41. https://doi.org/10.5296/jpag.v6i3.10000

Blunt, M. (1964). Cross-Carpeting. Parliamentary Affairs, 18(1), 82-91.

Chang, A. (2009). Reelection Incentives and Defection: Party switching in the Japanese Liberal Democratic Party. Japan: Institute of Political Science, Academia Sinica

Claphan, C. (1994). Democratization in Africa: Obstacles and Prospects, Third World Quarterly, 28.

Christenson, R. M., Engel, A. S., Jacobs D. N., Rejai, M., \& Watzer, H. (1972). Ideologies and Modern Politics, London: Thomas Nelson \& Sons Ltd.

Diamond, L. (1997) Consolidating the Third Wave Democracies, Baltimore, MD: Johns Hopkins University Press.

Edmund Burke (1729-1797) in Okwodu, N, Government in West Africa, Macmillan, London 1982.

Eme, O. I., \& Ogbochie, A. (2014). The Legal/Constitution Basis of Political Party Defection in Nigeria. Kuwait Chapter of Arabian Journal of Business and Management Review, 3(11). https://doi.org/10.12816/0018686

Fashagba, J. Y. (2014). Party Switching in the Senate under Nigeria's Fourth Republic. The Journal of Legislative Studies, 20(4), 516-541. https://doi.org/10.1080/13572334.2014.926169

Ghali, B. (1995). Democracy: A Newly Recognized Imperatives. Global Governance, 1(1). https://doi.org/10.1163/19426720-001-01-90000003

Heater, D. B. (1964). Political Ideas in the Modern World, London: George G. Harrap \& Co Ltd.

Held, D. (1993). Democracy: From City-States to Cosmopolitan Order in Held, D. (ed.) Prospects for Democracy, Cambridge Policy Press.

Hoeane, T. (2008). Floor-Crossing in South Africa: Entrenching or Undermining Democracy? South African Journal for Political Science and Public Administration, 27(2).

Huntington, S. P. (1968) Political Order in Changing Society, New Haven: Yale University Press.

IDEA (2000). Democracy in Nigeria, Continuing Dialogue(s) for Nation-Building, Capacity Building Series 10, Stockholm, Sweden.

Janda, K, Berry, J., \& Goldman, J. (1992). The Challenge of Democracy: American Government in Global Politics. US: Centage Learning. 
Ikhariale. (2015). The Dilemma of African opposition parties. Daily Independent, January 30, 2015.

Lafenwa, S. A. (2009). The legislature and the challenges of democratic governance in Africa: The Nigerian Case. In A seminar paper delivered at a conference on Governance and Development on Democratization in Africa, 4-5 pp.

Lamidi, K. O., \& Bello, M. L. (n.d). Party Politics and Future of Nigerian Democracy: An Examination of Fourth Republic. European Scientific Journal, 8(29).

LaPalombara, J., \& Weiner, M. (1966). Political Parties and Political Development: New Jersey: Princeton University Press. https://doi.org/10.1515/9781400875337

Minogue, M. (1997). The Principles and Practice of Good Governance. Law and Governance 4, British Council Briefing.

Nwokeoma, J. (2020). Imo state House of Opportunists. Retrieved from the punchng.com/imo-state-house-of-opportunists/

Oke, L. (2010). Democracy and Governance in Nigeria's Fourth Republic in Arowolo, D. Public Administration in Nigeria, (2010), Alabi-Eyo and Co Ltd.

Okwaraji, P. (2010) Political Party, Defection and the Law: The Tide. November 16, 2014. www.thetideonline.ng.com. Retrieved on March 9, 2015.

Omitola, B., \& Ogunnubi, O. R. (2016). Sub-National Legislature and Democratic Consolidation in Nigeria's Fourth Republic: Lessons from Osun State House of Assembly. Journal of Social Sciences. https://doi.org/10.3844/jssp.2016.160.170

Omotola, J. S. (2009) Nigerian Parties and Political Ideology, Journal of Alternative Perspectives in the Social Sciences, 1(3).

Omotoso, F. (1997). Political Parties in Kolawole (ed.) Readings in Political Science, Ibadan, Dekaal Publishers.

Opadere, O. S., \& Agbana, J. O. (2015). Cross Carpeting in Nigerian Politics: Some Legal and Moral Issues Generated. Frontiers of Legal Research, 3(2).

Osumah, O. (2009) Peoples Democratic Party and Governance in Nigeria, 1999-2007. Journal of Social Science, 9(3). https://doi.org/10.1080/09718923.2009.11892708

Robinson, F. (2010) Cross Carpeting; Not a Crime http://www.focusnigeria.com/crosscarpeting.htm Retrieved on May 13, 2013.

Rodee, C. C., Anderson, T. J., Christol, C. Q., \& Green, T. (1976). Introduction to Political Science, 3rd Edition, Tokyo: McGraw-Hill Kogakusha Ltd.

Sharma, M. P., Sadana, B. L., \& Kaur, P. (2012). Public Administration in Theory and Practice, India: Kitab Mahal Publishers.

Tordoff, W. (1997) Government and Politics in Africa, 3rd Edition. Bloomington: Indiana 


\section{Macrothink}

Journal of Public Administration and Governance ISSN 2161-7104 2021, Vol. 11, No. 1

University Press. https://doi.org/10.1007/978-1-349-25789-8

Wilson, J. O. (1992). American Government: Institutions and Politics, Lexington, MA; D.C. Health.

Yakubu, Y., \& Bamalli, M. J. (2019). Footloose Legislators: Implications of Legislative Cross-Carpeting on Multi-Party Politics in Nigeria's Fourth Republic. International Journal of Recent Innovations in Academic Research, 3(2).

\section{Copyright Disclaimer}

Copyright for this article is retained by the author(s), with first publication rights granted to the journal.

This is an open-access article distributed under the terms and conditions of the Creative Commons Attribution license (http://creativecommons.org/licenses/by/4.0/). 